\title{
WestVirginiaUniversity
}

THE RESEARCH REPOSITORY @ WVU

Graduate Theses, Dissertations, and Problem Reports

2006

\section{Media representation and portrayal of African-American athletes}

Justin Zackal

West Virginia University

Follow this and additional works at: https://researchrepository.wvu.edu/etd

\section{Recommended Citation}

Zackal, Justin, "Media representation and portrayal of African-American athletes" (2006). Graduate Theses, Dissertations, and Problem Reports. 1748.

https://researchrepository.wvu.edu/etd/1748

This Thesis is protected by copyright and/or related rights. It has been brought to you by the The Research Repository @ WVU with permission from the rights-holder(s). You are free to use this Thesis in any way that is permitted by the copyright and related rights legislation that applies to your use. For other uses you must obtain permission from the rights-holder(s) directly, unless additional rights are indicated by a Creative Commons license in the record and/ or on the work itself. This Thesis has been accepted for inclusion in WVU Graduate Theses, Dissertations, and Problem Reports collection by an authorized administrator of The Research Repository @ WVU. For more information, please contact researchrepository@mail.wvu.edu. 
Media Representation and Portrayal of African-American Athletes

\author{
Justin Zackal
}

Thesis submitted to the faculty of the Perley Isaac Reed School of Journalism at West Virginia University in fulfillment of the requirements for the degree of

\author{
Master of Science \\ in \\ Journalism
}
Dr. R. Ivan Pinnell, Chair
Dr. George Esper
Dr. Richard Krause John Temple

\title{
Morgantown, West Virginia 2006
}

Keywords: Media, African-Americans, Athletes, Sports 


\section{ABSTRACT \\ Media Representation and Portrayal of African-American Athletes}

Justin Zackal

The racial composition of athletes competing at major colleges and in professional sports in America is disproportioned to the general population and journalists that cover their sports. With African-Americans accounting for such a large contingent of athletes, how their race is perceived by society is often predicated on the coverage they receive. The purpose of this study is to look at the importance of media coverage of African-American athletes, and to show if White media scrutinize AfricanAmerican athletes more than they do White athletes. The misrepresentation of AfricanAmerican athletes in the press box could mean an unequal playing field in the arena of media discourse. The empirical evidence in this study takes a snapshot of professional football and examines the content of newspapers covering teams over a five-year span. Though presumptions can be made by the racial misrepresentation the context and frequency of the message should be most prevalent factor. 
TABLE OF CONTENTS

REVIEW OF LITERATURE.......................................................... 1

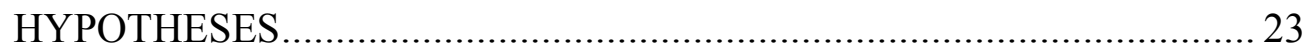

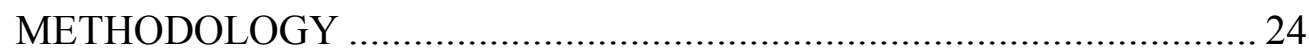

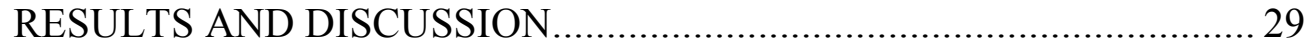

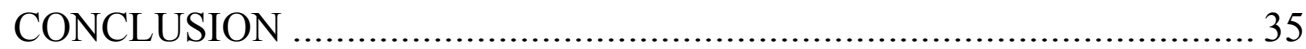

SUGGESTIONS FOR FUTURE RESEARCH..................................... 36

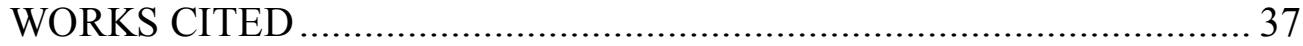

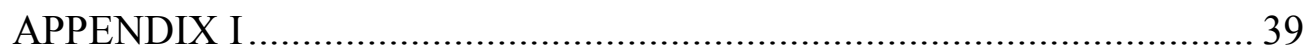

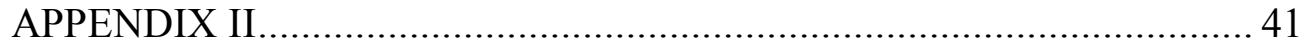




\section{REVIEW OF LITERATURE}

Race is one of the most delicate and most divisive issues in public discourse. The polar opposite of such rhetorical sidestepping is how the topic of sports often eases tension and becomes neutral to political, religious, and social sensitivities. It is the leisure interest and cultural notoriety of sports that gives legs to this type of public discourse. However, an overwhelming trend over the past half-century is the disproportional amount of African-American athletes competing in sports and accounting for most of the fodder in sports public discourse.

It is without question that sports transcends race. But does it work both ways in regards to racial perceptions in sports? Are all issues and opinions weighted on an equal playing field? Realizing how public opinions and perceptions are instilled leads to the one commonly held source: the media.

Significance is defined by the media. Though sports are the most objective information with wins and losses and statistics trumping any subjectivity, sports media fuel the public's needs for relevance and romanticism. The media tell us the score of the game, how many yards a football player ran, and the time it took a sprinter to run a race. The media tell us what records were broken, who the best athletes are, and how important gold medals are. But aspects that go beyond the facts are how they describe the events, what is deemed socially acceptable, and what conclusions are drawn from sporting events.

Take the Olympic games, for example. The Olympics have often been used as propaganda for nations boosting nationalism and influencing public perception. During the Cold War the Communist bloc emphasized athletics, which was reciprocated in the 
United States through the media for American nationalism. The media created a cultural significance for the U.S. hockey team's upset victory of the Soviet Union during the 1980 winter Olympics. The event will be forever referred to in angelic proportions as the "Miracle on Ice" thanks to the improvisation of television commentator Al Michaels belting the words, "Do you believe in miracles? Yes!," in the waning moments of the game. The moment was merely a group of college kids winning a hockey game against an opponent that was presumed to be superior. The media demonizing the Soviets and romanticizing the inspirational win for the sake of national pride made the significance.

But what happens when significance is not so easily demonstrated for the sake of partiality? What happens when significance conflicts with a diverse audience? That is indeed the case with the divisive issue of race in America. Even after African-Americans broke the color barrier in professional sports and today with Blacks accounting for the majority of the participants in several sports, negative portrayals in the media still linger. Before the Civil Rights movement, media portrayals of African-Americans were far more negatively blunt than they are today. But subliminal and unintentional stereotyping still occurs in sports coverage and consequently affects public perception.

Since the media often define athletic merit and significance, there are social pitfalls that befall even the most conscientious sports journalists. These include the stereotype that African-Americans are naturally athletic and do not work as hard as White athletes. There is also the stereotype that African-Americans have better reflexes but lack the intellect for certain positions. This permeates through the media when Blacks are referred to in their coverage with verbiage such as "raw athletic ability." AfricanAmericans were often described in these inhuman characteristics in the media during 
racial desegregation of professional sports that portrayed them as animals. These stereotypes lingered for years. As famous as Al Michaels' improvisation was at the 1980 Olympics, three years later renowned commentator Howard Cosell uttered his infamous improvisation on the nationally-televised Monday Night Football. Cosell exclaimed, "look at that little monkey run" when describing a play made by Alvin Garrett, an Black wide receiver for the Washington Redskins.

Outrageous racist remarks are easily earmarked as social blasphemy. But assessing African-Americans as better "natural" athletes and crediting their athletic merit simply on physicality has become a social taboo as well. Rewarding hard work on the athletic field and the idea of "nurture" is an American paradigm more commonly held and supported across all races. Social nature and social nurture is also a wrench to throw in the argument. Is there more pressure on African-Americans to succeed in athletics and conform to a certain identity? If that's the case, then how significant of a role do media have in framing this idea?

Before addressing these negative stereotypes of Black athletes, a reason for the use of stereotypes must be identified. Long before the Civil Rights movement and television had their profound impact on American culture, Walter Lippmann conducted a pioneering study of stereotypes in his 1922 book Public Opinion. According to Lippmann, stereotypes are "pictures in our heads" of people and events in the world. ${ }^{1}$ At the time Lippmann defined stereotypes, the printed word provided most of these "pictures." However, appraising information through the printed word became inefficient when replaced by photographs and moving pictures (television) that provide the image effortlessly:

\footnotetext{
${ }^{1}$ Walter Lippmann, Public Opinion (New York: The Free Press, 1922), 3.
} 
Any description in words, or even any inert picture, requires an effort of memory before a picture exists in the mind. But on the screen the whole process of observing, describing, reporting, and then imagining, has been accomplished for you. [...] There is an economy in this. For the attempt to see all things freshly and in detail, rather than as types and generalities, is exhausting, and among busy affairs practically out of the question.

The written word, photographs, moving pictures, and talking pictures are all manipulative forms of media that can enforce stereotypes. However, retention is stronger in the visual sense but since people cannot experience all events in a first-person account they are delivered a message from a secondary source that filters the information and becomes selective based on its own prejudices.

The limitations in the human cognitive process $^{2}$ that stereotypes arrive from causes consumers of media to interpret people and events that are slightly familiar as very familiar. ${ }^{3}$ Based on the media coverage, an athlete's public image - the likeness that attracts the most intrigue whether by tremendous athletic feats, social misconduct, or other distinctiveness — creates a slightly familiar depiction of his or her actual likeness, one that is in types and generalities. The media package athletes to economize other people's perceptions making it easy for an athlete or event to become very familiar. That is how a stereotype is born.

Stereotypes are derived in the media by their capabilities to package ideas and economize attention. This can be used against one particular athlete, a group of athletes, or all athletes. A little-known place kicker misses the game-winning field goal in the

\footnotetext{
${ }^{2}$ Perry R. Hinton, Stereotypes, Cognition and Culture (East Sussex, Britain: Psychology Press, 2000), 9. Hinton interprets Lippmann's idea as the human cognitive process that means the perception and 'knowledge' are arrived at through the process of constructing simplified 'pictures' of the world. Second, the contents are provided by the culture of the person. Third, both the stereotyping process and contents of the stereotype are 'faulty' because the resultant stereotype is almost certainly an inaccurate picture of the real world. Finally, the negative connotation of stereotypes and stereotyping is further supported by the belief that they are not flexible and not easy to change.
}

${ }^{3}$ Lippmann, 59. 
Super Bowl and he will forever be acknowledged as a player who cracks under pressure. A Samoan-born football player in the league is injury prone and suddenly there is a premonition held that future Samoan football players who enter the league are a liability. A high-profile quarterback in the league is charged with sexual assault - a news story that makes headlines beyond the sports page and reaches people who rarely follow sportsand all athletes are painted with the same brush as dangerous womanizers. These are all examples of how the "pictures" in our heads that are packaged by the media can speed up the human cognitive process, enforce stereotypes, and economize our attention by making what is slightly familiar very familiar.

If these knee-jerk responses are made because of the media economizing our attention then how are stereotypes enforced when a cognitive approach is made to evaluate social meaning? Merely repeatedly seeing an image on television of an athlete is not grounds for a lasting stereotype. Culture plays a role in continuing negative portrayals. Author and Waterloo University Professor of Psychology Ziva Kunda argues that social events are not analyzed in a visual sense revealing meaning and implications rather people play the role of making sense of social events and imbuing them with meaning. ${ }^{4}$ All social events, according to Kunda, are subjective and no two people imbue the same meaning. Determining how much control people can exert over automatic processes, including the suppression of unwanted negative stereotypes that serve as social barriers, is the crux of her argument. ${ }^{5}$ People are less inclined to "exert" themselves when imagery and imbued meaning are provided to them through the media.

\footnotetext{
${ }^{4}$ Ziva Kunda, Social Cognition: Making Sense of People (Cambridge, Mass.: Massachusetts Institute of Technology Press, 2001), 4.

${ }^{5}$ Ibid., 5 .
} 
If social events, such as sporting events, need to be imbued with meaning that furthers the media's need to create significance. People cannot economize their minds with straight reporting. Statistics alone cannot imbue the meaning in sporting events that the public desires. But in creating this significance, as Kunda points out, no two people imbue the same meaning and reporting can often be subjective. In other words, would a play-by-play announcer from the Soviet Union imbue the same meaning on the 1980 Olympic hockey game as Al Michaels and the rest of the American media? Obviously not. The responsibility lies in the media because their defining capabilities make up for the limitation of our cognitive process. "For the most part we do not first see, and then define, we define and then see," wrote Lippmann. "In the great blooming, buzzing confusion of the outer world we pick out what our culture has already defined for us, and we tend to perceive that which we have picked out in the form stereotyped for us by our culture." 6

Media provides us with culture. The public, even when told that stereotypes are faulty, struggles with this because it assumes that there must be truth in widely held views. People maintain their belief that there is truth in the stereotype by drawing on highly memorable examples. ${ }^{7}$ Examples are made highly memorable by visual and mental images that media imbue with meaning and significance.

Why, then, would the media have such a negative influence on the public when it comes to African-Americans in sports? In 2000, African-Americans made up 13 percent

\footnotetext{
${ }^{6}$ Lippmann, 54-55.

${ }^{7}$ Hinton, 18.
} 
of the United States population. ${ }^{8}$ Americans, who are predominantly White, enjoy following sports as a leisure activity. But with African-American participants dominating major sports a White American public often talks about Black athletes as apart of their leisure culture. In 2000, 77 percent of the players in the National Basketball Association (NBA) were African-American, along with 65 percent in the National Football League (NFL), and 15 percent in Major League Baseball (another 25 percent were Latino). African-Americans comprise 57 percent of the students playing National Collegiate Athletic Association (NCAA) Division I basketball and 47 percent of those playing NCAA Division I-A football. ${ }^{9}$

When you turn the microscope of racial composition around on the media there is a stark contrast. In 2000, the same year the above sport-by-sport racial composition was recorded, African-Americans accounted for a mere 10 percent of sports writers in the 1,600 daily newspapers in the United States, including only four Black sports editors in a city where there are professional franchises and 19 Black columnists. Nonetheless, those numbers doubled over a two-year span dating back to 1998, according to the National Association of Black Journalists. ${ }^{10}$ More recent studies at the University of Central Florida (UCF) show even more drastic numbers. The 2006 Racial and Gender Report Card of the Associated Press Sports Editors, published by UCF's Institute for Diversity and Ethics in Sport, revealed an astounding 94.7 percent of sports editors at 300 Associated Press-member newspapers are White. That report also showed alarming

\footnotetext{
${ }^{8}$ Jon Entine, Taboo: Why Black Athletes Dominate Sports and Why We're Afraid to Talk About It (New York: PublicAffairs, 2000), 19.

${ }^{9}$ Richard E. Lapchick, “Crime and Athletes: New Racial Stereotypes," Society 37, no. 3 (March/April 2000): 14.

${ }^{10}$ Ibid., 15.
} 
results for other staff position, including sports reporters (87.4 percent White), sports copy editors/designers (89.69), assistant sports editors (86.94), sports support staff/clerks (86.49), and sports columnists (89.93). The total for the sports staff reporter was 88.37 percent White. $^{11}$

Clearly there is a disparity in the social makeup of sports. Not to imply that White sports writers are racists, but based on the disproportioned racial makeup of sports journalists dating back to the Civil Rights movement to present time, it is possible that the reinforcement of African-American stereotypes in sports could have taken place over the years.

What are some of these stereotypes? James A. Rada, in conducting a study of television portrayals of African-Americans for the Journal of Broadcasting \& Electronic Media in 2000, identifies several general portrayals that are not necessarily but sometimes applied to athletes. They include, but are not limited to, the portrayal of African-Americans as inferior, lazy, dumb, dishonest, comical, unethical, crooked, insolent, bestial, brutish, power-hungry, money-hungry, and ignorant. ${ }^{12}$ His research, which coded television news stories with unfavorable or favorable portrayals, also points to the conclusion that television news portrayals of African-Americans often exhibit characteristics congruent with those of symbolic racism. ${ }^{13}$ Like the general symbolic

${ }^{11}$ Richard Lapchick with Jenny Brenden and Brian Wright, "The 2006 Racial and Gender Report Card of the Associated Press Sports Editors," Institute for Diversity and Ethics in Sport, 2006 [on-line .pdf] (Orlando, Fla.: University of Central Florida, accessed 11 July 2006); available from http://www.blackathlete.com/artman/uploads/APSE\%20Diversity\%20Study.pdf; Internet.

${ }^{12}$ James A. Rada, "A New Piece to the Puzzle: Examining Effects of Television Portrayals of African Americans," Journal of Broadcasting \& Electronic Media 44, no. 4 (Fall 2000): 705.

${ }^{13}$ 13Ibid. Symbolic racism is characterized by three main attributes. First, there is an antagonism toward African Americans pushing too hard to achieve equal rights. Second, there is resentment toward what are perceived to be special favors for African Americans, such as racial quotas in jobs or education, excessive access to welfare, special treatment by government, or unfair economic opportunities for African Americans. The third major component is a denial of the continuing existence of discrimination. 
racism Rada examines in television news, there are stereotypes distinct to athleticism that lingered since African-Americans first integrated professional sports. These stereotypes include Blacks as "natural" athletes who are more muscular, faster, can jump higher, and have quicker reaction skills, but despite their gifted athletic talents they are less intelligent, are poor leaders, have short tempers, have less stamina and perseverance, and are lazy when it comes to augmenting their talent. Some long-withstanding stereotypes are the inability for an African-American to quarterback a football team, become a point guard on a basketball team, or even coach a team. These preconceived notions have a tremendous impact on how African-Americans, minorities that are portrayed with more significance in sports than any other social construct, are portrayed in the public eye.

Richard E. Lapchick, author of nine books about race relations in sports, is the director of The Center for the Study of Sport in Society at Northeastern University. Through his research he realizes how important the portrayal of Black athletes are to the American culture:

[S]ports as it is currently being interpreted, now provides whites with the chance to talk about athletes in a way that reinforces those stereotypes about African Americans. With African Americans dominating the sports we watch most often [...] [w] hites tend to "think black" when they think about major sports. [...] Here is the equation we are dealing with as stereotypes of our athletes are built. Fans, who are mostly white, observe sport through a media filter which is overwhelming made up of white men. [...] The obvious result is the reinforcement of white stereotypes of athletes, who are mostly African American in our major sports. (Lapchick 2000, 15)

Black athletes are vulnerable in this sense because discussion conducted by a predominantly White mediator takes places within a predominantly White culture. All athletes are open to public skepticism because of their celebrity and salary—money that in the eyes of the general public is paid for out of the sports fans' pockets. But since 
African-Americans are the minority in the general public and a majority in professional sports there is increased skepticism based on social imbalances. Take these numbers, for example: The average salary in 2003 for the 77-percent African-American NBA was $\$ 4.9$ million and the 65-percent African-American NFL was $\$ 1.26$ million. ${ }^{14}$ The median White household income in the United States is $\$ 45,572$, according to a 2003 U.S Census report. ${ }^{15}$ These numbers cannot prove that Whites scrutinize or even resent Black athletes more than White athletes who also make the same money, but because of the precedent set by stereotypes and the sensitivities within the cultural and social construct it cannot be ignored.

There remains this societal misrepresentation of depicting only wealthy, successful African-Americans as professional athletes. The U.S. Census reports also show the median Black household income is $\$ 29,689$ and 24.4 percent of AfricanAmericans are living below the poverty line (compared to 12.5 percent for the entire U.S. population). ${ }^{16}$ Clearly, professional athletics is not a demographic snapshot of society.

The media are not to blame for any societal misrepresentation of AfricanAmericans. They simply cover the sports that happened to be dominated by a minority. But as the provider of images there is extreme delicacy in how the media portray them

\footnotetext{
14 "Decline is first since 1995," on ESPN.com [accessed on-line] (New York: Associated Press, 7 April 2004, accessed 2 December 2004); available from http://sports.espn.go.com/mlb/news/story?id=1777832; Internet.

${ }^{15}$ United States Census Bureau, "Income in the United States: 2003 Table: 1 Household Income by Race and Hispanic Origin and Income Definitions: 2002 and 2003” U.S. Census Bureau Reports, 2004 [on-line pdf] (Washington, D.C.: U.S. Government Printing Office, accessed 2 December 2004); available from http://www.census.gov/prod/2004pubs/p60-221.pdf; Internet

${ }^{16}$ United States Census Bureau, "Income Stable, Poverty Up, Numbers of Americans With and Without Wealth Insurance Rise, Census Bureau Reports," U.S. Census Bureau Reports, 2004 [on-line news release] (Washington, D.C.: Public Information Office, accessed 2 December 2004); available from http://www.census.gov/Press-Release/www/releases/archives/income wealth/002484.html; Internet.
} 
based on social ramifications. There is a racial backlash of these images. Edward

Taylor, Assistant Professor of Education at the University of Washington, writes:

Although fewer than 2,000 African Americans are in the NBA and more than 30,000 African Americans are physicians, we would never know it from the images that surround our children. Schools in the United States are also saturated images of black athlete stereotypes, recognizable on every playground and in every classroom. Not only does this reinforcement of physical ability over intellectual capability diminish the potential of young black men, but it also perpetuates the myth that the road to success is paved with sports contracts, not diplomas. ${ }^{17}$

African-Americans consider professional athletics as a viable means for success.

This can be damaging to society. In 1997, Sports Illustrated conducted a six-month survey polling the subject of race and sports to coincide with its special report, "What Ever Happened to the White Athlete?" Despite the slim chances of anyone, not just White athletes, making the pros, 55 percent of middle-school-age and high-school-age African-American males polled by SI (compared with 20 percent of White males) realistically think they may be good enough to play pro basketball, while 49 percent (compared with 27 percent of White) believe they could reach the NFL. "The kids are still looking at the popularity, the financial security of pro sports, even though statistics say you have a greater chance of being a rocket scientist," said Walt Frazier, a football coach at Miami's inner-city Carol City High quoted in SI's special report. ${ }^{18}$ But could you blame them? With many African-Americans in urban areas growing up in singleparent families and surrounded by crime and poverty, the only images of a wealthy African-Americans they see are athletes and musicians - and drug dealers. Bob Shannon, also an inner-city football coach, guided a predominantly African-American East St.

\footnotetext{
${ }^{17}$ Edward Taylor, "Bring in 'Da Noise': Race, Sports, and the Role of Schools," Educational Leadership 56, no. 7 (April 1999): 75.

${ }^{18}$ S.L. Price, "What Ever Happened to the White Athlete?," Sports Illustrated, 8 December 1997, 40.
} 
Louis High School team to six state championships. Quoted in the highly controversial book Pros and Cons: Criminals Who Play in the NFL, Shannon identifies problems with African-American youths:

Environment plays a tremendous role. When kids come out of an environment of poverty, gangs, and a lot of disrespect for the law, they learn a lot about 'getting over.' [...] [T] here are certain types of pressures on them that are not widespread on other kids. [...] The African-American athletes are affected by this more because a lot of them come out of these bad situations. Kids who grow up in middle-class backgrounds are more likely to learn the value of work. They see both parents getting up each day and going off to work and they learn that the things they have are a result of working. On the other hand, kids from the ghetto look around and see people who have things as a result of stealing or selling dope or some other method. When you have a man out there selling drugs and he's standing by the fanciest car in the neighborhood, kids pick up on that. ${ }^{19}$

Kids pick up on athletes, as well. Images of wealthy Black athletes encourage inner city kids to become professional athletes instead falling into the trappings of urban life. Granted, not all African-American athletes are from the ghetto, but the frequency of the media telling stories of Black athletes who come from the ghetto, avoid imminent death by gang violence, and achieve success in professional sports almost seems clichéd in today's sports media culture. The media celebrate these types of athletes because it is considered good for society, but there is never a caveat explaining the improbability of youths making it in professional sports. ${ }^{20}$ Not that the media should report on futile athletes - a comparison being all losers of the Powerball lottery instead of the one winner-but there is a social norm that the media produces. That is why the entire sports culture was taken aback by the 1994 movie Hoop Dreams, a 170-minute jaw-dropping

\footnotetext{
${ }^{19}$ Jeff Benedict and Don Yaeger. Pros and Cons: The Criminals Who Play in the NFL (New York: Warner Books, 1998), 171-172.

${ }^{20}$ Wood, M., "African-Americans Find Success, Obstacles in Sports and Entertainment Industries," [accessed on-line] (University of Virginia School of Law News \& Events, accessed 11 November 2004); available from http://www.law.virginia.edu/home2002/html/news/2001 02/winning.htm; Internet.
} 
documentary chronicling seven years in the life of two professional basketball hopefuls out of high school. The film, regarded as one of the top documentaries of all time, told the story people rarely see in the media of athletic and academic shortcomings of urban youths. "It's impossible to watch Hoop Dreams and not feel that American athletics exploits the fantasies of big-time wealth and celebrity that are envisioned by thousands of boys," wrote Washington Post columnist Hal Hinson. ${ }^{21}$

The media's portrayal of African-American athletes is not necessarily a pipe dream that entices urban youths to walk the straight-and-narrow path out of the ghetto and into the wealth of professional athletics. That is not why there are so many AfricanAmericans in sports. There is a distinct competitive edge Blacks have over Whites and the media have always maintained a certain stance in defining its significance. The cultural antithesis of Hoop Dreams is the 1992 movie White Men Can't Jump-the name says it all.

African-Americans' superiority in athletics over other races offers them a distinct cultural identity framed by the media. The success, however, comes with racial exploitation that stereotypes Blacks' natural athletic ability as their only contribution to society while also stereotyping Whites, making up for their lack of naturally gifted talent, as athletes that exude traditional values of hard work to overcome odds and achieve success. The White media first developed an inferiority complex before the Civil Rights movement having to report on the breakthrough success of African-Americans. This forced a double consciousness that kept any societal uprising in check and used Blacks'

${ }^{21}$ Hal Hinson, review of Hoop Dreams, [accessed on-line] (Washington Post, 4 November 1994, accessed 3 December 2004); available from http://www. washingtonpost.com/wpsrv/style/longterm/movies/videos/hoopdreamsnrhinson a01b70.htm; Internet. 
success in sports as a way to devalue intellectual achievements. ${ }^{22}$ The devalued intellect, a stereotype that is affixed to all athletes but more particular to African-Americans because of their cultural identity, is the problem that still faces public perception of Black athletes. Jon Entine, author of the book Taboo, focuses on this issue:

[T] he stereotype of the dumb jock, often tinged with racism, is far more pervasive, at least in the United States. In the 1960s, after the sports establishment finally opened its doors to young blacks, their immediate success triggered a reflexive backlash grounded in the lingering racist belief that blacks were not "smart enough" to hand the demands of "thinking" positions in sports, most notably quarterbacking in football. Whether consciously or as the result of deepseated prejudices, it was believed that blacks could not cope in situations that placed a premium on strategy.

So what came first, the chicken or the egg? Did the negative portrayal of Blacks as "natural" athletes come from a dismissive societal backlash in the White media in response to early their accomplishments, or was it born in the early accomplishments that were already established as acts of simple "natural" athletic feats?

African-Americans first excelled in boxing and in running. This was possible because unlike team sports they were not so easily dismissed as short on talent and no one could undercut the athletes because the sports were too objective. ${ }^{22}$ However, the fact that slaves were often competed in these sports as entertainment some hundred years earlier $^{23}$ did not provide grounds for much social dignity. These "cock fights" were a way to take African-Americans from the plantations to the athletic arenas. This parallel is used in a myth to determine why Blacks are "bred" to be genetically gifted, while even today it is used as a social parallel with many African-American civic leaders citing a

\footnotetext{
${ }^{22}$ Entine, 334.

${ }^{23}$ Entine, 140.
} 
parallel between White professional sports team owners and the abundance of Black athletes that play for them. ${ }^{24}$

But still, sports gave what little hope Blacks had in the face of social oppression. While Blacks first started to compete with Whites in teams sports on college teams in the late $1800 \mathrm{~s}^{25}$ and won their first Olympic first medals in $1904,{ }^{26}$ acceptance as fellow countrymen did come until the 1936 Olympics in Berlin when sprinter Jesse Owens took home four gold medals for the United States. The games held in Nazi Germany gave Americans a reason to rally behind their countrymen in opposition to Nazi propaganda and Aryan supremacists. Sports were later looked at by the media as the "Negro's best friend" at this time by some of the most prominent names in journalism such as Red Smith of the New York Times. ${ }^{27}$ Also during the late 1930s, African-American boxer Joe Louis was reaching fame by becoming subservient to White skepticism by not smiling and intimidating his White opponents the way Jack Johnson did in the 1920s before being socially exiled. ${ }^{28}$ Louis received the same stereotypes in the media, however. The jungle metaphors persisted. Louis was referred to in various ways portraying him as an animal out of Africa with "instinctive speed of the wild" and as a "magnificent animal that eats, sleeps, and fights" or as a "jungle killer." 29 But one distinction was made about Louis: he had no courage. "I see something in this colored man something so cold, so hard, so cruel that I wonder as to his bravery," wrote New York Daily News columnist Paul Gallico as

\footnotetext{
${ }^{24}$ Benedict, 172.

${ }^{25}$ Ibid., 146

${ }^{26}$ Ibid., 142.

${ }^{27}$ Ibid., 228.

${ }^{28}$ Entine, 151

${ }^{29}$ Entine, 190.
} 
quoted in Taboo. "Courage in the animal is desperation. Courage in the human is something incalculable and divine."30

Like Owens, Louis went toe-to-toe with Nazi Germany in competition with serious political implications. After putting on weight and attaining a newfound arrogance, Louis lost to Germany's Max Schmeling in 1936. The blow would augment European belief in the superior Aryan race. The loss reaffirmed African-American stereotypes, as well. But in June of 1938 when the two fighters met for a rematch, Louis battled from behind and defeated Schmeling in front of 70,000 roaring fans at Yankee Stadium. "Joe, we need muscles like yours to beat the Germans," remarked President Franklin D. Roosevelt before the fight. ${ }^{31}$ The win was one of the most prominent moments, not only in Black sports history, but in African-American's long road to social justice because it came at a points in history when Blacks were the butt of ridicule and they wanted nothing more than to have Louis win the fight and become the most famous man in America. ${ }^{32}$

Public sentiment still did not favor Black athletes despite Louis proving his ability to come back after defeat, which was significant because it defied the early stereotype that "natural" athletes lacked this type of resiliency. But from then on a double bind developed in which every achievement grew an even greater stereotype that denounced any social dignity and adapted blame by directing credit to another source. ${ }^{33}$ (Yes, the black athlete was resilient, but does he have the intellect?) The fact that Blacks now found themselves in this double consciousness proved that the "natural" athlete

\footnotetext{
${ }^{30}$ Ibid.

${ }^{31}$ Ibid, 194.

${ }^{32}$ Ibid, 195, quote from historian Thomas Sowell.

${ }^{33}$ Entine, 196.
} 
stereotype was indeed hatched by a societal backlash and not a misconception. AfricanAmericans were being undercut: the more athletic success they achieved the more it undermined their roles in society. The stereotype continued. "[T]o the vast majority, Louis, Owens, and other African-American athletes were super heroes who earned their triumphs welcome scraps of dignity in an otherwise difficult life," Entine reasoned. "Whether the black establishment liked it or not, by the late 1930s the athlete was coming to supplant the scholar and even the entertainer as the role model and symbol of black achievement in the minds of most Americans. ${ }^{\text {"34 }}$

Sports in America still had a procuring anglocentric sentiment in team sports despite its eventual integration. Segregation and quiet resegregation occurred in professional football in 1934 and 1946, respectively. In 1947, Jackie Robinson debuted with the Brooklyn Dodgers breaking the color barrier in baseball, and in 1950 the NBA's Boston Celtics drafted the first Black basketball player. This all came shortly before the U.S. Supreme Court's decision to declared the legal justification "separate but equal" unconstitutional. ${ }^{35}$ Team sports were becoming more and more integrated and by the late 1960s athletics were looked at as a device for racial harmony. The turbulent late 1960s, however, saw events that would see otherwise. In 1966, the Texas Western University basketball team, featuring an all-Black starting lineup defeated the all-White University of Kentucky team in the national champion ship game - the first such occurrence in NCAA tournament history. The stereotype at this time was that Black players were not disciplined enough to the win over the methodic style of play the White UK team

\footnotetext{
${ }^{34}$ Ibid.

${ }^{35}$ Ibid., 212.
} 
utilized. $^{36}$ Also during this time there was growing political dissension and the assassination of African-American Civil Rights leader Rev. Dr. Martin Luther King. This growing resentment was a Black Power movement that saw the possibility of a Black-boycotted Olympics in 1968. African-Americans competed but not without sprinters Tommie Smith and John Carlos demonstrating their disapproval for their nation. While on the podium during the playing of the "Star-Spangled Banner," Smith and Carlos held clenched fists in the air as a symbol of Black Power and political defiance. ${ }^{37}$ Sports were certainly not the icon of racial harmony because, like athletics have done through history, it was a false means for social significance for African-Americans. ${ }^{38}$

With Blacks' success in sports abound by the 1970s, the media were forced to make new portrayals. The number of Blacks in professional leagues was growing. And while they did not account for the resounding numbers of today, the small amount of Blacks were the most successful and recognizable athletes. This resulted in White inferiority issues that the media never had to deal with. Whites always had their own sports heroes and their own false racial justification. But in 1974 when AfricanAmerican baseball player Hank Aaron broke the highly coveted career home run record held by American folk hero Babe Ruth, athletic definitiveness was becoming far greater than social undercutting. Aaron received hate mail and death threats playing for a team in the racially-stubborn South, the Atlanta Braves, when he broke the record. ${ }^{39}$ He was not held with the same sentiment as a White sports hero like Ruth. This broke down more racial barriers but also led to a White inferiority complex.

\footnotetext{
${ }^{36}$ Entine, 223.

${ }^{37}$ Ibid., 225.

38 Ibid.

${ }^{39}$ Ron Fimrite, "Henry Aaron,” Sports Illustrated, 9 September 1994, 15.
} 
After African-American acceptance in sports finally occurred, there were still limitations as public perception started categorizing roles on teams. Though teams are to function as a unit and athletes are socialized to see only opponents and teammates and not race, ${ }^{40}$ the idea of position stacking would counter that theory and enforce new stereotypes. African-Americans are at times relegated to positions on teams that require only brute strength and reactive skills. ${ }^{41}$ This placed athletes in a position discrimination that would prevent them from leading a basketball team as a point guard or quarterbacking a football team that would command the respect of White teammates. These positions require profound intelligence, courage, leadership, and other qualities that reactive positions do not. Sports intelligence is often interpreted by the media where descriptors indicate certain athletes such as Black basketball star Michael Jordan excels the way a mechanic is good with his hands, ${ }^{42}$ while other athletes such as White quarterback Peyton Manning is a gifted scholar of the game who is successful because of his intellect and research of the opponent—nevermind the fact that his father and brother were and are NFL quarterbacks. The descriptors are not always true to form. Tigers Woods, the first famous Black professional golfer, was found in a 2003 study by Andrew Billings at Clemson University to have media describing him in success with typical White stereotypes but when he failed he was portrayed with African-American stereotypes. ${ }^{43}$ But more accurate conclusions can be drawn from teams sports where

${ }^{40}$ Tony N. Brown and others, eds., "There's No Race on the Playing Field: Perceptions of Racial Discrimination Among White and Black Athletes," Journal of Sport \& Social Issues 27 (May 2003): 165.

${ }^{41}$ Entine, 275.

${ }^{42}$ Ibid., 243.

${ }^{43}$ Andrew C. Billings, "Portraying Tiger Woods: Characterizations of a "Black" Athlete in a "White" Sport, Howard Journal of Communications 14, no. 1 (January 2003): 29. 
Blacks and Whites compete with and against each other on a presumably level playing field.

The reason more Blacks compete at only certain position is a product of stereotypes - Who would want to compete for a position they have less chances of succeeding? - but that same precept can be applied to Whites in a form of reverse racism. Since Whites spread most of their own inferiority complex in the media, White children are less likely to participate in team sports that African-Americans dominate at the professional level, according to the Sports Illustrated poll, and agree they cannot compete at the same level as Blacks. ${ }^{44}$

Negative portrayals and perceptions exist in the media and with prospective athletes, but what about the identity perceptions among athletes who have already gained success? In research led by Vanderbilt sociology professor Tony N. Brown surveying 533 Division I intercollegiate student athletes, Blacks who reported higher levels of athletic identity correlate low levels of racial identity. The correlations amongst Whites, however, were reversed. ${ }^{45}$ While, contrary to the same racial dichotomy of the society, Black and White athletes agreed that race is no longer a problem in the same study. "White intercollegiate student athletes with high athletic identity may experience dissonance because Blacks are often stereotyped as superior (i.e., natural) athletes," Brown reasoned. "Thus, the centrality of White student-athletes' racial identity may be heightened if they feel they are prejudged to be inferior athletes because of their race." ${ }^{46}$

${ }^{44}$ Price, 39.

${ }^{45}$ Tony N. Brown and others, eds., "There's No Race on the Playing Field: Perceptions of Racial Discrimination Among White and Black Athletes," Journal of Sport \& Social Issues 27 (May 2003): 175.

${ }^{46}$ Brown, 175. 
Many reverse traits to the social norm occur frequently in sports. The push for integration in sports represented a false sense of racial harmony. But now that Whites are the resounding minority, they are victimized and constrained by social forces. But this too is a false sense of White backlash. Unlike Blacks, Whites have always had media support and social justification. The media, in articles such as Sports Illustrated's "What Ever Happen to the White Athlete?" and less obvious in subliminal descriptors in reporting and commentating, portray Whites in a way that conforms to their desire: athletes want to be self-determining subjects of history not constrained by social forces. ${ }^{47}$ Their work is defined and made significant by public perception and the media. It is hard work that makes the athlete, not race. ${ }^{48}$

Race is sports, however. Denying that it isn't is preposterous based on the number of Black professional athletes whether by social and genetic means. As indicated by the cultural norms and social nurture in America, people "think black." And based on the success of African-Americans - 70 percent of the Olympic track and field records are held by the 1 of 8 athletes in the world that have African origin (95 percent of sprinting records $^{49}$ )—people "think black" in the natural abilities of Black athletes.

There are limitations for validating nature vs. nurture because inquiring this information is a social taboo. Race is a delicate issue that is often sidestepped. Many scientific studies such as the human evolutionary theory and African-Americans having fast-twitch muscle fibers were subsided by political correctness and the Civil Rights

\footnotetext{
${ }^{47}$ Kyle W. Kusz, "I Want to be the Minority: The Politics of Youthful White Masculinities in Sport and Popular Culture in 1990s America," Journal of Sport \& Social Issues 25 (November 2001): 412.

${ }^{48}$ Entine, 9.

${ }^{49}$ Ibid., 31.
} 
movement. ${ }^{50}$ Media have also shied away from the subject of nature vs. nurture. ${ }^{51}$

Instead, the issues of African-American dominance in sports are not defined by scientists or sociologists but by journalists. Since the media define significance and perception, the sports page is both a laboratory and symposium where the barometer is the stereotypical precedent—-stereotypes such as the Black athlete being naturally gifted but lazy and lacking intellect and social dignity. "People think if you say blacks are better athletically, you're saying they're dumber," said respected author and sports reporter Frank DeFord. "But when [a White athlete does something remarkable in athletics], nobody thinks his IQ goes down." 52

Because of perception, long poisoned by societal backlash and undercutting, a tangled web connecting athletes to race and race to athletes has developed within media and public discourse. This "playing field" of opinions is not weighted equally and though race transcends sports because of definitiveness of winning and losing, the scoreboard the media is keeping for public perception is anything but definite.

\footnotetext{
${ }^{50}$ Entine, 220.

${ }^{51}$ Ibid., 231.

${ }^{52}$ Ibid., 5.
} 


\section{HYPOTHESES}

H1 - Sports journalists are more likely to report on White (non-AfricanAmerican) athletes in greater proportion to African-American athletes.

H2 - More negative coverage of African-American athletes is reflected in coverage following local team losses.

H3 - More positive coverage of White athletes is reflected in coverage following local team wins. 


\section{METHODOLOGY}

Proving whether or not journalists are racially biased is nearly an impossible feat to achieve through empirical evidence. The cognizance of avoiding racial stereotyping in news coverage would result in reaching for subconscious evidence that presents too many variables. That same social cognizance in the field of science has made a taboo issue of research proving that African-Americans' innate athletic abilities are superior to other ethnic groups. Any scientific proof that African-Americans possess more natural ability would not only stereotype the entire race but it would also belittle the acquired abilities that many African-American athletes work hard to earn.

There is one undeniable truth that sports journalists hold the responsibility of awarding merit - and demerit, for that matter - in their coverage. Obviously, journalists cannot alter the score or any statistical facts, but they are the ones that analyze the events. They work with an empty canvas before producing copy that shape public discourse. Most importantly, for this study, they determine why a team wins or loses by opinion and choosing factual evidence.

This is where a subconscious racial bias can creep into news coverage. After all, these mostly-White journalists are providing a product for mostly-White readers who wanted to know about a subject that matter that is made up of mostly-Black athletes. The goal of the following study is to determine whether or not journalists sympathize with White athletes in their coverage, and if they are more apt to scrutinize African-American athletes.

The researcher chose to analyze the coverage of the National Football League for the following reasons: 1.) Football is widely regarded as the most popular sport in 
America, and 2.) Approximately 70 percent of all players in the National Football League (NFL) are African-American. ${ }^{53}$

Newspaper coverage was selected for the study because its content provides consumers of media with the most finality and permanence to an event compared to the fleeting form of broadcast journalism. Print journalists have more range and selectiveness in whom and what they cover rather than a television commentator or radio analyst which talks more about the ongoing circumstance and situation. In other words, this is the best form of media to empirically sample journalists' bias and sympathy to a group of athletes.

Six newspapers from six different markets were selected for use in the study. The goal was to choose newspapers from diverse regions of the nation to have a broad enough range of samples. However, the goal was also to select newspapers with smaller circulation because they offer more of an intimacy with those who follow the specific teams. The intent of writers for more nationally-read newspapers like the Washington Post and New York Times would be far different than say a newspaper in Green Bay, Wisconsin.

The researcher chose the most significant newspaper in six middle-to-smallmarket cities with NFL teams. The St. Louis Dispatch (St. Louis Rams) represents the culture of the Midwest, the Seattle Times (Seattle Seahawks) represents the Pacific West, the Tampa Tribune (Tampa Bay Buccaneers) represents the South, the Denver Post (Denver Broncos) represents the Mountain West, and the Pittsburgh Post-Gazette

${ }^{53}$ Richard Lapchick, "The 2004 Racial and Gender Report Card: National Football League," Institute for Diversity and Ethics in Sports, 24 May 2005 [on-line] (Orlando, Fla.: University of Florida, accessed 11 July 2006; available from www.rpi.edu/ fouche/Sports/Summaries/NFL.pdf; Internet. 
(Pittsburgh Steelers) and the Cleveland Plain-Dealer (Cleveland Browns) represents the East. The reason there are two cities in the East is because that region is more populated. All of the articles relevant to game coverage from 60 issues, 10 from each newspaper, were used in this study. Two issues from each of the last five seasons (2000$05)$ were selected. The researcher chose issues of the day following one loss and one win during each season. This maximizes the content since there is more coverage on that day than any other day during the year. Since most coverage is predicated on expectations in the earlier weeks of the season and failed or exceeded expectations in the latter weeks of the season, the researcher chose the win and loss closest to the midpoint of the season (Week 8). For example, if a team lost during Week 8, that game's coverage applies to the study while the previous week's win during Week 7 is also used. If a team is on a long winning or losing streak during Week 8 , the researcher chose the earliest win or loss in the sequence to avoid atypical coverage during a team's late-season playoff crunch.

As far as how the articles were coded and evaluated, the researcher sought three major areas of significance. The evidence used in this study focused on the coverage African-American football players in proportion to non-African-American football players in three facets: 1.) the frequency of coverage, 2.) positive coverage, and 3.) negative coverage. Also, to truly gauge sentiments following losses and wins only the players from the team that the newspaper covers was included in the study.

As a result of the lack of scientific evidence, the myriad of variables, and the social taboo, the topic of natural abilities and nurtured abilities exists on in the context of corresponding positive and negative coverage. Historically, many sports journalists prior to the Civil Rights Movement would demerit the positive events of African-Americans by 
crediting it to natural ability. That is why nurtured skill is the societal ideal in public discourse. This study, as mentioned above, cannot read between the lines for the sake of empirical analysis. Therefore, any description of events within the context of good natural ability is considered positive.

To avoid this type of backhanded bias, because it is too difficult to prove intent with empirical evidence, a clear definition of negativity was established by the researcher. A "negative" attribution in coverage is the description of any athlete or an athlete's actions that cause a team to fail (lose). A "positive" attribution is coverage is the description of an athlete or an athlete's actions that causes a team to succeed (win). Any passing reference of a player that cannot fall into either category, such as describing an injury, is labeled "neutral."

Other clarifications for gathering data samples are as follows: All players listed on a roster, active or non-active, for a particular game are to be used in the study. Any references to former players will not be included. An attribution to a game other than the selected game or an unrelated event that takes place away from the confines of the game setting will only be used as a neutral reference.

The goal for compiling this data is to establish levels of sympathy for White athletes or bias toward African-American athletes. Positive results denote a percentage far from the typical racial composition of the NFL. For example, if in the selected year's racial composition of the league is 70-percent African-American and 30-percent White, then all frequency of coverage should maintain reasonably close percentage points to that standard. If White players' positive actions are presented in articles more frequently than 30 percent following games, then White sympathizing is positive. The same goes for 
Blacks with negative coverage following a loss. Finally, the overall attribution of White and Black players is also a factor in this research. 


\section{RESULTS AND DISCUSSION}

After conducting the research and compiling the data, the researcher found that two of the three hypotheses were found to be negative. Collectively, the six newspapers referenced American-American players and non-African-American players, which will hereafter be called "Nons," in accordance with the racial composition of the entire league. The racial composition of the league for this study was 67.1 percent AfricanAmerican, an average of the three times that the information was compiled by the Institute for Diversity and Ethics in Sport between 2001 and 2005. In the 60 issues sampled, a total of 6,729 players were referenced in articles, including 4,312 AfricanAmericans and 2,426 Nons. That means 64.08 percent of all players attributed in the coverage were African-American and 36.05 were Nons. That is accurate and reflective of the makeup of the entire league. This implies that reporters are objective in who they cover, attribute action, and voice opinions toward. This indicates that the hypothesis is false that journalists would reference White players and Nons at a higher frequency than the proportion of the NFL's racial makeup. Hence, it appears, Hypothesis One, sports journalists are more likely to report on White (non-African-American) athletes in greater proportion to African-American athletes, was not confirmed by the data.

Table 1-A

NFL Players Referenced in 60 Issues of Daily Newspapers from 2001-05

\begin{tabular}{|l|l|l|}
\hline Total Players & African-Americans & Non-African-Americans \\
\hline 6,729 & 4,312 & 2,426 \\
\hline $\begin{array}{l}\text { \% of Total Players in the } \\
\text { 60 Issues }\end{array}$ & $64.08 \%$ & 36.05 \\
\hline $\begin{array}{l}\text { Average \% in the NFL } \\
\text { from 2001-05 }\end{array}$ & $67.1 \%$ & $32.9 \%$ \\
\hline
\end{tabular}


The journalists are clearly reporting on the players of different race equally and in proportion to the makeup of the league. However, what about the content of the journalists' message? Just because journalists write about the players in fair frequency, it does not mean they are fair in complimenting or criticizing them. The final two hypotheses predicted that the journalists would be more critical of African-Americans with condescending coverage, especially following losses, and that journalists would sympathize with the White players by complimenting them more in their coverage, particularly following wins.

Hypotheses Two, the prediction that more negative coverage of African-American athletes is reflected in coverage following local team losses, was not confirmed by the data. Not only were there more Nons referenced after losses, but the percentage of negative attributions exceeded those of African-Americans. A total of 2,951 players were referenced in the 30 issues following losses. Of that total, $57.13 \%$ were AfricanAmerican players and 42.87 were Nons, which is closer than the $67.1 \%$-to-32.9\% league standard. The most surprising outcome was the negative attribution following losses: only $13.18 \%$ of all players referenced were African-American negative attribution while the Nons negative attribution exceeded the African-Americans with $14.03 \%$ of the total attribution. The numbers are even more pronounced when taking the percentage among specific race reference. Of total non-African-American references, $32.73 \%$ were negative, meaning that Nons and their events were described negatively at a higher rate compared to Nons positive and neutral events. 
Table 2-A

\section{NFL Players Referenced in 30 Issues of Daily Newspapers from 2001-05 Following Losses}

\begin{tabular}{|l|l|l|}
\hline Total Players & African-Americans & Non-African-Americans \\
\hline 2,951 & 1,686 & 1,265 \\
\hline $\begin{array}{l}\text { \% of Total Players in the } \\
30 \text { issues following losses }\end{array}$ & $57.13 \%$ & $42.87 \%$ \\
\hline $\begin{array}{l}\text { Average \% in the NFL } \\
\text { from 2001-05 }\end{array}$ & $67.1 \%$ & $32.9 \%$ \\
\hline $\begin{array}{l}\text { \% of Negative Attribution } \\
\text { to the Total Players }\end{array}$ & $13.18 \%$ & $14.03 \%$ \\
\hline $\begin{array}{l}\text { \% of Negative Attribution } \\
\text { among own racial group }\end{array}$ & $23.07 \%$ & $32.73 \%$ \\
\hline
\end{tabular}

Hypotheses Three, the prediction that more positive coverage of White athletes is reflected in coverage following local team wins, was the only hypothesis that was confirmed by the data. A rare finding in this study was having a negative or positive attribution for a particular group exceed the more-likely neutral attribution. This was the case for non-African-Americans following wins. Of the 3,778 player attributions following wins in the 30 issues, 550 were positive references to Nons, which is a percentage of 14.56. The neutral attribution of Nons following wins was 496 for 13.13\%. This is the only case among all racial groups for wins, losses, overall, where neutral is eclipsed by a negative or positive reference. The results were also positive compared to the results of African-Americans. There was a difference of 18.13 percentage points (32.72\% African-American to $14.56 \%$ Non) which was closer than the 34.2 percentage point split for the total players in the league $(67.1 \%$ to $32.9 \%)$. Journalists were more apt 
to point out positive actions of White players following wins, thus suggesting they sympathize with them and want to celebrate their actions to satisfy White readers.

Table 3-A

NFL Players Referenced in 30 Issues of Daily Newspapers from 2001-05 Following Wins

\begin{tabular}{|l|l|l|}
\hline Total Players & African-Americans & Non-African-Americans \\
\hline 3,778 & 2,626 & 1,161 \\
\hline $\begin{array}{l}\text { \% of Total Players in the } \\
30 \text { issues following wins }\end{array}$ & $69.51 \%$ & $30.73 \%$ \\
\hline $\begin{array}{l}\text { Average \% in the NFL } \\
\text { from 2001-05 }\end{array}$ & $67.1 \%$ & $32.9 \%$ \\
\hline $\begin{array}{l}\text { \% of Positive Attribution } \\
\text { to the Total Players }\end{array}$ & $32.72 \%$ & $14.56 \%$ \\
\hline $\begin{array}{l}\text { \% of Positive Attribution } \\
\text { among own racial group }\end{array}$ & $47.07 \%$ & $47.37 \%$ \\
\hline
\end{tabular}

As in any study there were several variables to take into consideration in this study, but none more crucial than position stacking. In the year 2003, the NFL was 77percent White at the quarterback position. The quarterback position is the most scrutinized position in football because the quarterback touches the ball on every offensive play. If there is any variable that may skew the numbers in this study it comes from the quarterback position. Of the starting quarterbacks in the 60 games covered in this study, 57 of them were White. The data sample is too small to compare whether or not journalists are more critical of Black quarterbacks than White quarterbacks. However, it must be taken into account that majority of negative attributions in this study for non-African-Americans are based on references to the quarterback. The total attributions to Nons was 2,426, while 1,055 of those attributions were to the starting quarterback. That means $43.49 \%$ of references to Nons were to starting quarterbacks. 
Included in this figure is $36.79 \%$ of neutral references, $44.58 \%$ of positive references, and, mostly notably, $55.81 \%$ of negative references. This could mean two things: 1.$)$ journalists are more critical of quarterbacks in general, or 2.) they expect more from White athletes since this is the one position that White culture can cling to for racial validation in a sport where the majority of the athletes are African-American.

Table 3-A

\section{Non-African-American NFL Starting Quarterbacks Referenced in 60 Issues of Daily Newspapers from 2001-05}

\begin{tabular}{|l|l|l|}
\hline & $\begin{array}{l}\text { Non-African-American } \\
\text { Starting Quarterbacks }\end{array}$ & Total Non-African-Americans \\
\hline Total References & $1,055(43.49 \%)$ & 2.426 \\
\hline Positive References & $358(44.58 \%)$ & 803 \\
\hline Negative References & $293(55.81 \%)$ & 525 \\
\hline Neutral References & $404(36.79 \%)$ & 1,098 \\
\hline
\end{tabular}

Another variable of note is how the data collector must use a subjective opinion in some cases. For example, if the copy in an article describes how a quarterback was sacked five times, does this suggest a negative attribution to the quarterback for his inability to escape pressure or his offensive line for its inability to block? In this study, the researcher tried to determine the context of how the event is being described. If the sentences leading up to the description referenced how immobile to quarterback was or if it was accompanied by poor passing statistics, then the event was labeled negative.

Otherwise, it was marked as a neutral attribution. There are other instances such as this where the researcher had to look at previous and ensuing remarks to determine the context. 
The final variable of note is in the nature of newspaper journalism and the "flocking" mentality. An example of this is when there is an outspoken athlete who always offers a great sound bite or quote. This would increase mostly neutral attribution unless the quote was describing the actions, positively or negatively, of the player or his teammate.

Journalists are also most selective when there is not an obvious storyline for a game, but when the story is obvious it can create some outlying, skewed numbers in the results of the study. For example, when the Pittsburgh Steelers lost to the Cleveland Browns in 2001, kicker Kris Brown missed three field goals costing the Steelers the win. The non-African-American negative references for that issue were $79.59 \%$ of the total, with Kris Brown, who is White, receiving 55 of the issue's 129 player attributions (only 13 other references were made to non-African-American players). 


\section{CONCLUSION}

The 2006 Racial and Gender Report Card of the Associated Press Sports Editors suggests that coverage of athletes is not fair or accurate and that there needs to be voices in the sports media from people of different backgrounds. While the report does not point fingers, the researchers call this unprecedented report a "baseline" and "a point to measure progress." ${ }^{, 54}$ Future research by the Institute of for Diversity and Ethics in Sports will show if there is progress. But what about the content of these White "voices." Are these messages and analysis really fair?

According to this study on the coverage of NFL teams by their home newspapers the voices are, for the most part, fair and accurate. The overall referencing of athletes is in compliance with the racial composition of the entire league. The attribution of success and failure of the team is appointed to the racial dispersion of the league. While the scrutiny of the quarterback position is good fodder for future research, this snapshot of media discourse in accordance to race is encouraging. Sports are all based on rules so that the players have a level playing field and this seems to be reflective in the playing field of media discourse.

\footnotetext{
${ }^{54}$ Lapchick, Brenen, Wright, 1.
} 


\section{SUGGESTIONS FOR FUTURE RESEARCH}

There are a few points of emphasis for future research based on the findings of this study. The most significant is the impact the quarterback position has on this study. The racial composition and the role of the quarterback is distinct and unlike the rest of the football players. Removing the quarterback from this study would limit the sample size but would increase the accuracy of the data. Also, since the quarterback is such a seminal player in terms the actions of the game and the scrutiny of the media, comparing the coverage of African-American quarterbacks to the coverage of White quarterbacks would be a useful study.

Having conducted a study paramount on the actions of the games, another suggested point of emphasis would be the off-the-field coverage and portrayal of AfricanAmericans. Athletes are such integral figures of societal and public discourse that all aspects of their actions should be considered in analysis of their representations and portrayal. 


\section{WORKS CITED}

Benedict, Jeff, and Don Yaeger. Pros and Cons: The Criminals Who Play in the NFL. New York: Warner Books, 1998.

Billings, Andrew C. "Portraying Tiger Woods: Characterizations of a 'Black' Athlete in a 'White' Sport." Howard Journal of Communications 14, no. 1 (January 2003): 29-37.

Entine, Jon. Taboo: Why Black Athletes Dominate Sports and Why We're Afraid to Talk About It. New York: PublicAffairs, 2000.

Hinton, Perry R. Stereotypes, Cognition and Culture. East Sussex, Britain: Psychology Press, 2000.

Kusz, Kyle W. "I Want to be the Minority: The Politics of Youthful White Masculinities in Sport and Popular Culture in 1990s America." Journal of Sport \& Social Issues 25 (November 2001): 390-416.

Kunda, Ziva. Social Cognition: Making Sense of People. Cambridge, Mass.: Massachusetts Institute of Technology Press, 2001.

Lapchick, Richard E. “Crime and Athletes: New Racial Stereotypes.” Society 37, no. 3 (March/April 2000): 14-20.

Lapchick, Richard. "The 2004 Racial and Gender Report Card: National Football League.” Institute for Diversity and Ethics in Sports, 24 May 2005 [on-line] (Orlando, Fla.: University of Florida, accessed 11 July 2006; available from www.rpi.edu/ fouche/Sports/Summaries/NFL.pdf; Internet.

Lapchick, Richard, and Jenny Breden, Brian Wright. "The 2006 Racial and Gender Report Card of the Associated Press Sports Editors." Institute for Diversity and Ethics in Sport, 2006 [on-line .pdf] (Orlando, Fla.: University of Central Florida, accessed 11 July 2006); available from http://www.blackathlete.com/artman/uploads/APSE\%20Diversity\%20Study.pdf; Internet.

Lippmann, Walter. Public Opinion. New York: The Free Press, 1922.

Taylor, Edward. "Bring in 'Da Noise': Race, Sports, and the Role of Schools." Educational Leadership 56, no. 7 (April 1999): 75-78.

Rada, James A. “A New Piece to the Puzzle: Examining Effects of Television Portrayals of African-Americans." Journal of Broadcasting \& Electronic Media 44, no. 4 (Fall 2000): 705-715. 
Ron Fimrite, "Henry Aaron,” Sports Illustrated, 9 September 1994, 15.

S.L. Price, "What Ever Happened to the White Athlete?" Sports Illustrated, 8 December 1997, 18.

Tony N. Brown and others, eds. "There's No Race on the Playing Field: Perceptions of Racial Discrimination Among White and Black Athletes." Journal of Sport \& Social Issues 27 (May 2003): 162-182.

United States Census Bureau. "Income in the United States: 2002 Table: 1 Household Income by Race and Hispanic Origin and Income Definitions: 2001 and 2002." Census Bureau Reports, 2003 [on-line pdf] (Washington, D.C.: U.S. Government Printing Office, accessed 2 December 2004); available from http://www.census.gov/prod/2003pubs/p60-221.pdf; Internet

United States Census Bureau. "Income Stable, Poverty Up, Numbers of Americans With and Without Wealth Insurance Rise." Census Bureau Reports, 2004 [on-line news release] (Washington, D.C.: Public Information Office, accessed 2 December 2004); available from http://www.census.gov/PressRelease/www/releases/archives/income_wealth/002484.html; Internet.

"Decline is first since 1995," on ESPN.com [accessed on-line] (New York: Associated Press, 7 April 2004, accessed 2 December 2004); available from http://sports.espn.go.com/mlb/news/story?id=1777832; Internet.

Hal Hinson, review of Hoop Dreams. [ accessed on-line] (Washington Post, 4 November 1994, accessed 3 December 2004); available from http://www.washingtonpost.com/wpsrv/style/longterm/movies/videos/hoopdreamsnrhinson_a01b70.htm; Internet.

Wood, M. "African-Americans Find Success, Obstacles in Sports and Entertainment Industries." [accessed on-line] (University of Virginia School of Law News \& Events, accessed 11 November 2004); available from http://www.law.virginia.edu/home2002/html/news/2001_02/winning.htm; Internet. 


\section{APPENDIX I}

The following chart is a listing of all newspaper issued used in the study. This chart is

also a key for the composite results in APPENDIX II.

\begin{tabular}{|l|l|}
\hline 01 Cleveland L & Cleveland Plain-Dealer, 12 November 2001 \\
\hline 02 Cleveland L & Cleveland Plain-Dealer, 4 November 2002 \\
\hline 03 Cleveland L & Cleveland Plain-Dealer, 10 November 2003 \\
\hline 04 Cleveland L & Cleveland Plain-Dealer, 8 November 2004 \\
\hline 05 Cleveland L & Cleveland Plain-Dealer, 14 November 2005 \\
\hline 01 Cleveland W & Cleveland Plain-Dealer, 19 November 2001 \\
\hline 02 Cleveland W & Cleveland Plain-Dealer, 18 November 2002 \\
\hline 03 Cleveland W & Cleveland Plain-Dealer, 17 November 2003 \\
\hline 04 Cleveland W & Cleveland Plain-Dealer, 18 October 2004 \\
\hline 05 Cleveland W & Cleveland Plain-Dealer, 7 November 2005 \\
\hline
\end{tabular}

\begin{tabular}{|c|c|}
\hline 01 Denver L & Denver Post, 19 November 2001 \\
\hline 02 Denver L & Denver Post, 12 November 2002 \\
\hline 03 Denver L & Denver Post, 4 November 2003 \\
\hline 04 Denver L & Denver Post, 1 November 2004 \\
\hline 05 Denver L & Denver Post, 24 October 2005 \\
\hline 01 Denver $\mathrm{W}$ & Denver Post, 12 November 2001 \\
\hline 02 Denver $\mathrm{W}$ & Denver Post, 18 November 2002 \\
\hline 03 Denver W & Denver Post, 17 November 2003 \\
\hline 04 Denver W & Denver Post, 8 November 2004 \\
\hline 05 Denver $\mathrm{W}$ & Denver Post, 14 November 2005 \\
\hline
\end{tabular}

\begin{tabular}{|l|l|}
\hline 01 Pittsburgh L & Pittsburgh Post-Gazette, 5 November 2001 \\
\hline 02 Pittsburgh L & Pittsburgh Post-Gazette, 18 November 2002 \\
\hline 03 Pittsburgh L & Pittsburgh Post-Gazette, 3 November 2003 \\
\hline 04 Pittsburgh L & Pittsburgh Post-Gazette, 20 September 2004 \\
\hline 05 Pittsburgh L & Pittsburgh Post-Gazette, 21 November 2005 \\
\hline 01 Pittsburgh W & Pittsburgh Post-Gazette, 12 November 2001 \\
\hline 02 Pittsburgh W & Pittsburgh Post-Gazette, 4 November 2002 \\
\hline 03 Pittsburgh W & Pittsburgh Post-Gazette, 10 November 2003 \\
\hline 04 Pittsburgh W & Pittsburgh Post-Gazette, 8 November 2004 \\
\hline 05 Pittsburgh W & Pittsburgh Post-Gazette, 7 November 2005 \\
\hline
\end{tabular}




\begin{tabular}{|c|c|}
\hline 01 Seattle L & Seattle Times, 5 November 2001 \\
\hline 02 Seattle L & Seattle Times, 4 November 2002 \\
\hline 03 Seattle L & Seattle Times, 10 November 2003 \\
\hline 04 Seattle L & Seattle Times, 15 November 2004 \\
\hline 05 Seattle L & Seattle Times, 3 October 2005 \\
\hline 01 Seattle W & Seattle Times, 12 November 2001 \\
\hline 02 Seattle W & Seattle Times, 11 November 2002 \\
\hline 03 Seattle W & Seattle Times, 3 November 2003 \\
\hline 04 Seattle W & Seattle Times, 8 November 2004 \\
\hline 05 Seattle W & Seattle Times, 7 October 2005 \\
\hline
\end{tabular}

\begin{tabular}{|l|l|}
\hline 01 St. Louis L & St. Louis Post-Dispatch, 29 October 2001 \\
\hline 02 St. Louis L & St. Louis Post-Dispatch, 25 November 2002 \\
\hline 03 St. Louis L & St. Louis Post-Dispatch, 3 November 2003 \\
\hline 04 St. Louis L & St. Louis Post-Dispatch, 8 November 2004 \\
\hline 05 St. Louis L & St. Louis Post-Dispatch, 14 November 2005 \\
\hline 01 St. Louis W & St. Louis Post-Dispatch, 12 November 2001 \\
\hline 02 St. Louis W & St. Louis Post-Dispatch, 4 November 2002 \\
\hline 03 St. Louis W & St. Louis Post-Dispatch, 10 November 2003 \\
\hline 04 St. Louis W & St. Louis Post-Dispatch, 15 November 2004 \\
\hline 05 St. Louis W & St. Louis Post-Dispatch, 31 October 2005 \\
\hline
\end{tabular}

\begin{tabular}{|l|l|}
\hline 01 Tampa L & Tampa Tribune, 19 November 2001 \\
\hline 02 Tampa L & Tampa Tribune, 21 October 2002 \\
\hline 03 Tampa L & Tampa Tribune, 3 November 2003 \\
\hline 04 Tampa L & Tampa Tribune, 15 November 2004 \\
\hline 05 Tampa L & Tampa Tribune, 7 November 2005 \\
\hline 01 Tampa W & Tampa Tribune, 12 November 2001 \\
\hline 02 Tampa W & Tampa Tribune, 4 November 2002 \\
\hline 03 Tampa W & Tampa Tribune, 27 October 2003 \\
\hline 04 Tampa W & Tampa Tribune, 8 November 2004 \\
\hline 05 Tampa W & Tampa Tribune, 21 November 2005 \\
\hline
\end{tabular}




\section{APPENDIX II}

Composite results of the study

Issue $=$ see APPENDIX I

$\mathrm{W} / \mathrm{L}=$ coverage following a win or a loss

Totals $=$ total players referenced

$\mathrm{T}-\mathrm{AA}=$ total African-Americans referenced

$\mathrm{T}$-Non $=$ total non-African-Americans referenced

$\mathrm{AA}+=$ African-American positive references

Non $+=$ non-African-American positive references

AA $-=$ African-American negative references

Non - = non-African-American negative references

AA $\sim=$ African-American neutral references

Non $\sim=$ non-African-American neutral references

$\begin{array}{llrrrrrrrrr}\text { Issue } & \text { W/L } & \text { Totals } & \text { T-AA } & \text { T-Non } & \text { AA }+ & \text { Non }+ & \text { AA - } & \text { Non - } & \text { AA } ~ & \text { Non } \\ \text { 01 Cleveland } & \text { L } & 106 & 72 & 34 & 26 & 14 & 11 & 7 & 35 & 13 \\ \text { 02 Cleveland } & \text { L } & 100 & 55 & 45 & 34 & 9 & 4 & 18 & 17 & 18 \\ \text { 03 Cleveland } & \text { L } & 75 & 57 & 18 & 21 & 4 & 18 & 2 & 18 & 12 \\ \text { 04 Cleveland } & \text { L } & 68 & 19 & 49 & 11 & 9 & 0 & 23 & 8 & 17 \\ \text { 05 Cleveland } & \text { L } & 103 & 78 & 25 & 26 & 7 & 14 & 12 & 38 & 6 \\ \text { 01 Cleveland } & \text { W } & 126 & 113 & 13 & 56 & 0 & 4 & 4 & 53 & 9 \\ \text { 02 Cleveland } & \text { W } & 132 & 113 & 19 & 54 & 9 & 7 & 3 & 52 & 7 \\ \text { 03 Cleveland } & \text { W } & 141 & 76 & 65 & 42 & 35 & 0 & 2 & 34 & 28 \\ \text { 04 Cleveland } & \text { W } & 140 & 88 & 52 & 49 & 29 & 6 & 11 & 33 & 12 \\ \text { 05 Cleveland } & \text { W } & 177 & 101 & 76 & 49 & 35 & 7 & 12 & 45 & 29 \\ \text { 01 Denver } & \text { L } & 135 & 68 & 67 & 19 & 8 & 17 & 24 & 32 & 35 \\ \text { 02 Denver } & \text { L } & 93 & 51 & 42 & 4 & 3 & 1 & 26 & 46 & 13 \\ \text { 03 Denver } & \text { L } & 126 & 71 & 55 & 25 & 9 & 15 & 16 & 31 & 30 \\ \text { 04 Denver } & \text { L } & 104 & 44 & 60 & 13 & 7 & 6 & 34 & 25 & 19 \\ \text { 05 Denver } & \text { L } & 135 & 85 & 50 & 25 & 14 & 18 & 10 & 42 & 26 \\ \text { 01 Denver } & \text { W } & 134 & 91 & 43 & 33 & 20 & 6 & 3 & 52 & 20 \\ \text { 02 Denver } & \text { W } & 108 & 42 & 66 & 20 & 22 & 0 & 5 & 22 & 39 \\ \text { 03 Denver } & \text { W } & 154 & 95 & 59 & 38 & 33 & 0 & 3 & 57 & 23 \\ \text { 04 Denver } & \text { W } & 70 & 59 & 11 & 30 & 6 & 0 & 1 & 29 & 4 \\ \text { 04 Denver } & \text { W } & 139 & 106 & 33 & 36 & 19 & 7 & 1 & 63 & 13 \\ \text { 01 Pittsburgh } & \text { L } & 129 & 61 & 68 & 20 & 8 & 10 & 39 & 31 & 21 \\ \text { 02 Pittsburgh } & \text { L } & 58 & 33 & 25 & 12 & 2 & 11 & 6 & 10 & 17 \\ \text { 03 Pittsburgh } & \text { L } & 78 & 60 & 18 & 19 & 11 & 24 & 3 & 17 & 4 \\ \text { 04 Pittsburgh } & \text { L } & 68 & 22 & 46 & 10 & 8 & 4 & 14 & 4 & 28 \\ \text { 05 Pittsburgh } & \text { L } & 59 & 34 & 25 & 6 & 9 & 10 & 4 & 18 & 12 \\ \text { 01 Pittsburgh } & \text { W } & 174 & 123 & 51 & 71 & 23 & 12 & 9 & 40 & 19 \\ \text { 02 Pittsburgh } & \text { W } & 78 & 57 & 21 & 26 & 13 & 2 & 1 & 28 & 8 \\ \text { 03 Pittsburgh } & \text { W } & 104 & 82 & 22 & 52 & 19 & 5 & 2 & 25 & 1 \\ \text { 04 Pittsburgh } & \text { W } & 89 & 58 & 31 & 21 & 16 & 4 & 4 & 33 & 11 \\ \text { 05 Pittsburgh } & \text { W } & 98 & 53 & 45 & 24 & 21 & 6 & 3 & 23 & 21\end{array}$




\begin{tabular}{|c|c|c|c|c|c|c|c|c|c|c|}
\hline Issue & W/L & Totals & T-AA & T-Non & $\mathrm{AA}+$ & Non + & $A A-$ & Non - & $\mathrm{AA} \sim$ & Non \\
\hline 01 Seattle & L & 73 & 35 & 38 & 16 & 4 & 9 & 15 & 10 & 19 \\
\hline 02 Seattle & L & 72 & 60 & 12 & 15 & 6 & 11 & 0 & 34 & 6 \\
\hline 03 Seattle & L & 86 & 78 & 8 & 19 & 3 & 34 & 3 & 25 & 2 \\
\hline 04 Seattle & L & 83 & 58 & 25 & 19 & 2 & 13 & 9 & 26 & 14 \\
\hline 05 Seattle & L & 93 & 47 & 46 & 14 & 12 & 10 & 10 & 23 & 24 \\
\hline 01 Seattle & W & 102 & 85 & 17 & 56 & 13 & 0 & 0 & 29 & 4 \\
\hline 02 Seattle & W & 115 & 77 & 38 & 44 & 23 & 1 & 0 & 32 & 10 \\
\hline 03 Seattle & W & 96 & 88 & 8 & 22 & 2 & 7 & 1 & 59 & 5 \\
\hline 04 Seattle & W & 112 & 87 & 25 & 37 & 13 & 2 & 3 & 48 & 9 \\
\hline 05 Seattle & W & 121 & 98 & 23 & 51 & 17 & 0 & 0 & 47 & 6 \\
\hline 01 St.Louis & $\mathrm{L}$ & 141 & 69 & 72 & 22 & 19 & 14 & 23 & 33 & 30 \\
\hline 02 St.Louis & L & 147 & 53 & 94 & 9 & 25 & 16 & 17 & 28 & 52 \\
\hline 03 St.Louis & $L$ & 74 & 37 & 37 & 5 & 2 & 8 & 10 & 24 & 25 \\
\hline 04 St.Louis & L & 89 & 49 & 40 & 13 & 2 & 8 & 14 & 28 & 24 \\
\hline 05 St.Louis & L & 96 & 61 & 35 & 10 & 6 & 21 & 6 & 30 & 23 \\
\hline 01 St.Louis & W & 95 & 68 & 27 & 31 & 8 & 7 & 3 & 30 & 16 \\
\hline 02 St.Louis & W & 127 & 99 & 28 & 51 & 6 & 1 & 3 & 47 & 19 \\
\hline 03 St.Louis & W & 160 & 84 & 76 & 26 & 23 & 15 & 23 & 43 & 30 \\
\hline 04 St.Louis & W & 110 & 70 & 40 & 27 & 13 & 6 & 0 & 37 & 27 \\
\hline 05 St.Louis & W & 122 & 62 & 69 & 25 & 36 & 0 & 0 & 37 & 33 \\
\hline 01 Tampa & $\mathrm{L}$ & 144 & 82 & 62 & 10 & 17 & 23 & 19 & 49 & 26 \\
\hline 02 Tampa & $L$ & 98 & 52 & 46 & 19 & 10 & 9 & 14 & 24 & 22 \\
\hline 03 Tampa & L & 122 & 81 & 41 & 9 & 4 & 3 & 11 & 69 & 26 \\
\hline 04 Tampa & $\mathrm{L}$ & 54 & 46 & 8 & 11 & 1 & 8 & 4 & 27 & 3 \\
\hline 05 Tampa & L & 142 & 68 & 74 & 7 & 18 & 39 & 21 & 22 & 35 \\
\hline 01 Tampa & W & 121 & 98 & 23 & 58 & 15 & 6 & 0 & 34 & 8 \\
\hline 02 Tampa & W & 156 & 90 & 66 & 47 & 28 & 1 & 7 & 42 & 31 \\
\hline 03 Tampa & W & 196 & 173 & 23 & 78 & 9 & 2 & 2 & 93 & 12 \\
\hline 04 Tampa & W & 162 & 94 & 68 & 45 & 29 & 3 & 5 & 46 & 34 \\
\hline 05 Tampa & W & 119 & 96 & 23 & 37 & 15 & 7 & 0 & 52 & 8 \\
\hline totals & & 6729 & 4312 & 2426 & 1705 & 803 & 513 & 525 & 2089 & 1098 \\
\hline \multirow{2}{*}{\multicolumn{2}{|c|}{$\begin{array}{l}\text { percent of race } \\
\text { percent of } 6.729\end{array}$}} & & 64.08 & 36.05 & 39.54 & 33.1 & 11.9 & 21.64 & 48.45 & 45.26 \\
\hline & & & & & 25.34 & 11.93 & 7.62 & 7.8 & 31.04 & 16.31 \\
\hline
\end{tabular}

